\title{
Implementasi Model Pembelajaran Tutor Sebaya (Peer Tutoring) untuk Meningkatkan Aktivitas dan Hasil Belajar Tata Hidang
}

\author{
Ni Luh Astrini Laksemiwati
}

SMK Negeri 2 Singaraja, Indonesia

\section{A R T I C L E I N F O}

Article history:

Received 19 November 2018

Received in revised form

30 December 2018

Accepted 10 January 2019

Available online 20

February 2019

\section{Kata Kunci:}

model pembelajaran

Tutor Sebaya, aktivitas

belajar, hasil belajar

siswa.

Keywords:

peer tutor learning model,

learning activities, student

learning outcomes.

\begin{abstract}
A B S T R A K
Tujuan dari diadakannya penelitian ini adalah untuk meningkatkan aktivitas belajar dan hasil belajar tata hidang melalui implementasi model pembelajaran Tutor Sebaya pada siswa Kelas XI A5 SMK Negeri 2 Singaraja Tahun Pelajaran 2017/2018. Penelitian ini adalah penelitian tindakan kelas (PTK). Subjek yang dipilih dalam penelitian ini adalah siswa XI A5 SMK Negeri 2 Singarja dengan jumlah siswa 41 orang yang terdiri dari 23 orang siswa laki-laki dan 18 orang siswa perempuan, sedangkan objek penelitian ini pada mata pelajaran tata hidang adalah materi tata cara pelayanan makanan dan minuman di restoran menggunakan model pembelajaran Tutor Sebaya. Data aktivitas belajar siswa dikumpulkan dengan menggunakan lembar observasi aktivitas belajar siswa yang telah dipersiapkan, sedangkan data hasil belajar siswa dikumpulkan dengan pemberian tes esai kepada siswa. Analisis data yang digunakan pada penelitian ini menggunakan analisis data deskriptif. Berdasarkan analisis data yang dilakukan dapat disimpulkan bahwa implementasi model Tutor Sebaya dapat meningkatkan aktivitas dan hasil belajar Tata Hidang siswa kelas XI A5 SMK Negeri 2 Singaraja Tahun Pelajaran 2017/2018.
\end{abstract}

A B S T R A C T

The purpose of this research is to improve learning activities and learning outcomes in the subject of serving procedure through the Implementation of Peer Tutor Learning Model in class XI A5 students of Vocational School 2 Singaraja in academic year of 2017/2018. This is classroom action research with a total of 41 students consisting of 23 male students and 18 female students. The object of this study was food and beverage services procedure in restaurants by using peer tutor learning model. The data of students' learning activity were collected using the observation sheet that had been prepared, while the data of students' learning outcome were collected by giving essay test to students. Descriptive data analysis was used to analyze the data. Based on the data analysis, it can be concluded that the implementation of Peer Tutor Model can improve the activities and learning outcomes of class XI A5 students of Vocational School 2 Singaraja in academic year of 2017/2018. 


\section{Pendahuluan}

Pendidikan merupakan usaha sadar dan terencana untuk mewujudkan suasana belajar dan proses pembelajaran atau pelatihan agar peserta didik secara aktif dapat mengembangkan potensi dirinya secara terus menerus sepanjang hidup yang diharapkan dapat memiliki kekuatan spiritual keagamaan, emosional, pengendalian diri, kepribadian, kecerdasan, akhlak mulia, serta keterampilan yang diperlukan dirinya dan masyarakat. Pemerintah selalu berusaha untuk meningkatkan kualitas pendidikan dengan berbagai cara seperti mengganti kurikulum, meningkatkan kualitas guru melalui penataran-penataran, memberi dana Bantuan Operasional Sekolah (BOS) dan sebagainya. Pemerintah mengatur kebijakan pendidikan sesuai dengan fungsi dan tujuan Pendidikan Nasional dalam UU RI No. 20 tahun 2003 SISDIKNAS Bab II Pasal 3,yaitu:

Pendidikan nasional berfungsi mengembangkan kemampuan dan membentuk watak serta peradaban bangsa yang bermartabat dalam rangka mencerdaskan kehidupan bangsa, bertujuan untuk berkembangnya potensi peserta didik agar menjadi manusia yang bertakwa kepada Tuhan YME, berakhlak mulia, sehat, berilmu, cakap, kreatif, mandiri dan menjadi warga negara yang demokratis serta bertanggug jawab.

Menghayati isi dari UU No. 20 tahun 2003 tersebut, peneliti berpendapat bahwa tugas seorang pendidik memang berat, sebab kemajuan suatu bangsa ditentukan oleh keberhasilan pendidikan dari bangsa itu sendiri. Jika seorang guru atau pendidik tidak berhasil mengembangkan potensi peserta didik maka negara itu tidak akan maju, sebaliknya jika guru atau pendidik berhasil mengembangkan potensi peserta didik, maka terciptalah manusia yang cerdas, terampil, dan berkualitas. Menurut Wina Sanjaya (2006:19), peran guru adalah: "Sebagai sumber belajar, fasilitator, pengelola, demonstrator, pembimbing, dan evaluator". Sebagai sumber belajar dan motivator guru harus mampu meningkatkan pemahanan dan membangkitkan motivasi siswa agar aktivitas proses pembelajaran berhasil dengan baik. Salah satu cara untuk meningkatkan pemahaman dan aktivitas siswa dalam proses pembelajaran adalah dengan mengganti model pembelajaran yang selama ini tidak diminati lagi oleh siswa, seperti pembelajaran yang dilakukan dengan ceramah dan tanya-jawab, model pembelajaran ini membuat siswa jenuh dan tidak kreatif. Suasana belajar mengajar yang diharapkan adalah menjadikan siswa sebagai subjek yang berupaya menggali sendiri, memecahkan sendiri masalah-masalah dari suatu konsep yang dipelajari, sedangkan guru lebih banyak bertindak sebagai motivator dan fasilitator. Situasi belajar yang diharapkan di sini adalah siswa yang lebih aktif.

Belajar adalah merupakan suatu proses, suatu kegiatan dan bukan suatu hasil atau tujuan. Belajar bukan hanya mengingat, akan tetapi lebih luas daripada itu, yakni mengalami. Hasil belajar bukan suatu penguasaan hasil latihan melainkan perubahan kelakuan" (Hamalik, 2005: 37). Belajar ialah suatu proses usaha yang dilakukan seseorang untuk memperoleh suatu perubahan tingkah laku yang baru secara keseluruhan, sebagai hasil pengalamanya sendiri dalam interaksi dengan lingkunganya" (Slameto, 2003:2). Dampak pengajaran adalah hasil yang dapat diukur dengan segera atau secara langsung. Sedangkan dampak pengiring adalah hasil belajar siswa yang tampak secara tidak langsung atau merupakan transfer hasil belajar" (Dimyati dan Mudjiono, 2006:295). Jadi dapat disimpulkan hasil belajar adalah sesuatu yang dicapai atau diperoleh siswa berkat adanya usaha atau pikiran yang mana hal tersebut dinyatakan dalam bentuk penguasaan, pengetahuan dan kecakapan dasar yang terdapat dalam berbagai aspek kehidupan sehingga nampak pada diri indivdu penggunaan penilaian terhadap sikap, pengetahuan dan kecakapan dasar yang terdapat dalam berbagai aspek kehidupan sehingga nampak pada diri individu perubahan tingkah laku secara kuantitatif (Setiawan Hendri, 2014).

Fenomena seperti diatas merupakan permasalahan yang perlu segera ditemukan alternatifalternatif pemecahannya. Salah satu upaya yang dapat dijadikan alternatif pemecahan masalah tersebut adalah dengan menerapkan pembelajaran yang meningkatkan pemahaman dan aktivitas belajar siswa melalui "model tutor sebaya (peer tutoring)" pada mata pelajaran tata hidang yang merupakan salah satu mata pelajaran produktif yang ada di SMK Negeri 2 Singaraja, pada dasarnya Sekolah Menengah Kejuruan menciptakan peserta didik yang siap kerja, dalam upaya menyiapkan peserta didik yang handal dan memiliki kesiapan kerja, mereka dibekali dengan beberapa mata diklat yang dikelompokkan menjadi 3 program yaitu program normatif, program adaptif, dan program produktif. Program produktif adalah kelompok mata diklat yang berfungsi membekali peserta didik agar memiliki kompetensi kerja sesuai Standar Kompetensi Kerja Nasional Indonesia (SKKNI). Oleh karena itu, dengan implementasi model pembelajaran tutor sebaya pada mata pelajaran tata hidang, diharapkan peserta didik dapat lebih aktif dalam bertanya atau mengeluarkan pendapat, karena peserta didik malu bertanya atau mengeluarkan pendapat langsung di dalam kelas, melainkan ke teman/tutor dalam kelompoknya. Pada pembelajaran tutor sebaya ini, sebagian peserta didik diajak untuk menjadi tutor atau sumber belajar dan tempat 
bertanya bagi temannya, sehingga bimbingan secara individu kepada peserta didik akan menjadi lebih optimal.

Penelitian ini dikuatkan oleh penelitian sebelumnya yang dilakukan oleh nurmala (2016) yang menyatakan penerapan model pembelajaran tutor sebaya dapat meningkatkan hasil belajar siswa kelas $\mathrm{V}$ SDN 20 Tolitoli pada operasi hitung campuran bilangan bulat

Berdasarkan uraian tersebut peneliti mencoba menerapkan salah satu model pembelajaran, yaitu model pembelajaran tutor sebaya untuk mengungkapkan apakah dengan model pembelajaran tutor sebaya dapat meningkatkan pemahaman dan aktivitas belajar siswa dalam mata pelajaran tata hidang. Dari latar belakang tersebut maka peneliti dalam penelitian ini mengambil judul "Implementasi Model Pembelajaran Tutor Sebaya untuk Meningkatkan Aktivitas dan Hasil Belajar Tata Hidang pada Siswa Kelas XI A5 SMK Negeri 2 Singaraja Tahun Pelajaran 2017/2018.

\section{Metode}

Penelitian tindakan kelas ini dilaksanakan di SMK Negeri 2 Singaraja Lokasinya di Jalan Srikandi No. 9 Singaraja. Penelitian tindakan kelas ini dilaksanakan selama satu semester dimulai sejak minggu ketiga bulan Agustus sampai akhir bulan Nopember 2018.

Subyek yang dijadikan sumber data dalam penelitian tindakan kelas ini adalah siswa kelas XI A5 SMK Negeri 2 Singarja dengan jumlah siswa 41 orang terdiri dari 23 orang siswa laki-laki dan 18 orang siswa perempuan. Obyek penelitian ini adalah aktivitas dan hasil belajar mata pelajaran tata hidang pada materi tata cara pelayanan makanan dan minuman di restoran dengan menggunakan model pembelajaran tutor sebaya.

Salah satu cara untuk meningkatkan aktivitas dan hasil belajar siswa dalam proses pembelajaran adalah dengan mengganti model pembelajaran yang selama ini tidak diminati lagi oleh siswa, seperti pembelajaran yang dilakukan dengan ceramah dan tanya-jawab, model pembelajaran ini membuat siswa jenuh dan tidak kreatif. Suasana belajar mengajar yang diharapkan adalah menjadikan siswa sebagai subjek yang berupaya menggali sendiri, memecahkan sendiri masalah-masalah dari suatu konsep yang dipelajari, sedangkan guru lebih banyak bertindak sebagai motivator dan fasilitator. Situasi belajar yang diharapkan di sini adalah siswa yang lebih aktif.

Fenomena seperti diatas merupakan permasalahan yang perlu segera ditemukan alternatifalternatif pemecahannya. Salah satu upaya yang dapat dijadikan alternatif pemecahan masalah tersebut adalah dengan menerapkan pembelajaran yang meningkatkan pemahaman dan aktivitas belajar siswa melalui "model tutor sebaya (peer tutoring)" pada mata pelajaran tata hidang yang merupakan salah satu mata pelajaran produktif yang ada di SMK Negeri 2 Singaraja, pada dasarnya Sekolah Menengah Kejuruan menciptakan peserta didik yang siap kerja, dalam upaya menyiapkan peserta didik yang handal dan memiliki kesiapan kerja, mereka dibekali dengan beberapa mata diklat yang dikelompokkan menjadi 3 program yaitu program normatif, program adaptif, dan program produktif. Program produktif adalah kelompok mata diklat yang berfungsi membekali peserta didik agar memiliki kompetensi kerja sesuai Standar Kompetensi Kerja Nasional Indonesia (SKKNI). Oleh karena itu, dengan penerapan model pembelajaran tutor sebaya pada mata pelajaran tata hidang, diharapkan peserta didik dapat lebih aktif dalam bertanya atau mengeluarkan pendapat, karena peserta didik malu bertanya atau mengeluarkan pendapat langsung di dalam kelas, melainkan ke teman/tutor dalam kelompoknya. Pada pembelajaran tutor sebaya ini, sebagian peserta didik diajak untuk menjadi tutor atau sumber belajar dan tempat bertanya bagi temannya, sehingga bimbingan secara individu kepada peserta didik akan menjadi lebih optimal.

Penelitian ini akan dilaksanakan dalam 2 siklus pembelajaran. Dimana masing-masing siklus pembelajaran terdiri dari empat tahap tindakan yaitu tahap perencanaan tindakan, pelaksanaan tindakan, observasi tindakan, dan tahap refleksi. Hasil refleksi digunakan sebagai penyempurnaan-penyempurnaan tindakan untuk siklus berikutnya, sedangkan refleksi yang digunakan pada siklus terakhir digunakan untuk membuat suatu rekomendasi-rekomendasi dari hasil penelitian ini.

Pembagian materi pada tiap siklus didasarkan pada keterkaitan antara kompetensi dasar dan indikator pencapaian hasil belajar siswa. Siklus I dan II dapat digambarakan seperti gambar 1. 


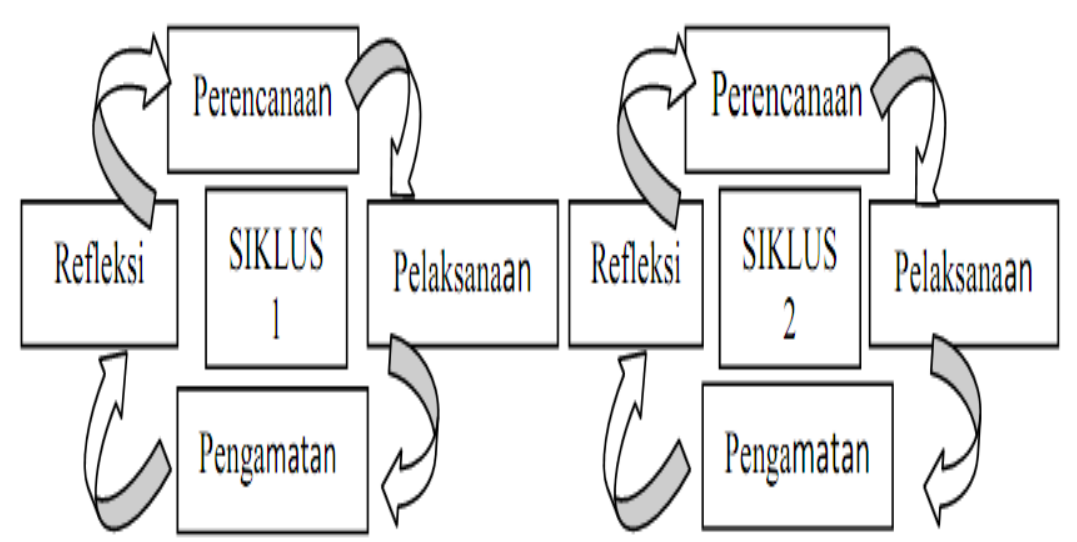

Gambar 1. Siklus PTK

Observasi dilakukan oleh peneliti selama proses pembelajaran dengan implementasi model tutor sebaya untuk meningkatkan aktivitas dan hasil belajar tata hidang pada materi tata cara pelayanan makanan dan minuman di restoran. Observasi dilakukan dengan menggunakan lembar observasi aktivitas belajar siswa yang telah dipersiapkan. Sedangkan untuk mengukur hasil belajar dilakukan dengan pemberian tes essay kepada siswa terkait materi tata cara pelayanan makanan dan minuman di restoran yang telah disiapkan oleh peneliti pada akhir siklus. Setelah data aktivitas dan hasil belajar siswa terkumpul, selanjutnya dilakukan analisis data dengan menggunakan analisis deskriptif.

\section{Hasil dan Pembahasan}

Sebelum penelitian tindakan kelas ini dilaksanakan, peneliti mengadakan observasi dan pengumpulan data dari kondisi awal kelas yang akan diberikan tindakan, yaitu kelas XI A5 SMK Negeri 2 Singaraja tahun pelajaran 2017/2018.

Kondisi awal ini perlu diketahui agar kiranya penelitian ini sesuai dengan apa yang diharapkan oleh peneliti, apakah benar kiranya kelas ini perlu diberi tindakan yang sesuai dengan apa yang akan diteliti oleh peneliti yaitu implementasi model pembelajaran tutor sebaya untuk meningkatkan aktivitas dan hasil belajar tata hidang pada materi tata cara pelayanan makanan dan minuman di restoran.

Untuk mengungkapkan kondisi awal dari kelas yang menjadi subyek tindakan maka peneliti melakukan langkah-langkah sebagai berikut:

Perencanaan

Untuk mengetahui kondisi awal dari kelas XI A5 SMK Negeri 2 Singaraja tahun pelajaran 2017/2018 maka terlebih dahulu peneliti merencanakan observasi pada kegiatan belajar mengajar yang dilakukan di kelas XI A5 pada saat mata pelajaran tata hidang berlangsung. Observasi ini dilakukan untuk mengetahui aktivitas dan hasil belajar siswa sebelumnya dengan menggunakan metode pembelajaran ceramah.

Pelaksanaan

Pelaksanaan ini untuk mengukur kemampuan awal siswa, di awali dengan pengajaran yang dilakukan oleh guru mata pelajaran tata hidang dengan menggunakan metode pembelajaran ceramah. Pada pembelajaran ini peneliti mengamati kejadian-kejadian yang terjadi secara rinci pada saat guru menyampaikan materi pelajaran dan pada akhir pelajaran guru memberikan soal post test sebagai alat evaluasi.

Hasil pengamatan

Berdasarkan observasi yang dilakukan oleh peneliti didapatkan bahwa pada pengajaran yang dilakukan, guru masih menggunakan cara pengajaran yang tradisional yaitu dengan menggunakan metode pembelajaran ceramah. Pada pembelajaran berlangsung terlihat siswa asik dengan kegiatannya sendiri yang tidak ada kaitannya dengan apa yang disampaikan oleh guru. Terlihat peserta didik bermainmain dengan temannya tanpa memperdulikan apa yang disampaikan oleh guru pengajar.

Hasil tes yang dikerjakan oleh siswa pada soal post test yang telah dirancang oleh guru, setelah diadakan koreksi maka didapatkan hasil yang kurang memuaskan. Hasil koreksi tes awal dari 41 siswa yang ada di kelas XI A5 tersebut didapatkan hasil, 18 siswa mendapatkan nilai di bawah KKM, sedangkan siswa yang telah tuntas atau yang telah mendapatkan nilai di atas KKM berjumlah 23 siswa. Dari paparan 
hasil nilai yang didaptkan siswa, tampak bahwa yang mencapai ketuntasan belajar hanya 23 siswa atau sebesar 56,09\% dari jumlah siswa yang ada di kelas XI A5 SMK Negeri 2 Singaraja tahun pelajaran $2017 / 2018$.

\section{Refleksi}

Bertolak dari kondisi awal tersebut, maka perlu diadakan suatu tindakan untuk meningkatkan aktivitas dan hasil belajar siswa pada mata pelajaran tata hidang. Berdasarkan kondisi awal tersebut, maka peneliti merencanakan tindakan penelitian dengan implementasi model pembelajaran tutor sebaya di kelas XI A5 SMK Negeri 2 Singaraja tahun pelajaran 2017/2018.

Pembahasan Hasil Penelitian

Pada pelaksanaan pembelajaran siklus I tidak terlihat adanya siswa yang bermain-main ataupun asyik mengerjakan pekerjaan yang lain, semuanya fokus dalam mengerjakan tugas masing-masing. Pada pelaksanaan kegiatan kerja kelompok tampak adanya siswa yang mengalami kesulitan dalam mengerjakan tugas dan untuk mengatasi kesulitannya tersebut mereka bertanya kepada ketua kelompok yang berperan sebagai tutor sebaya yang tugasnya membantu dan menjelaskan kesulitan yang dihadapi temannya. Namun ada pula siswa yang mengalami hambatan dalam mengerjakan tugas tersebut langsung bertanya kepada peneliti atau guru pengajar.

Hasil post tes yang diberikan setelah dikoreksi oleh peneliti didapatkan hasil sebagai berikut: dari 41 siswa ada 18 siswa yang mendapatkan nilai kurang dari 72 ( 2.85) yang artinya nilainya masih di bawah KKM atau belum tuntas, dan ada 23 siswa yang telah mendapatkan nilai diatas KKM atau telah tuntas.

Dengan melihat titik lemah yang terjadi pada sebagian kecil siswa berkenaan konsep dasar mengenai materi tata cara pelayanan makanan dan minuman di restoran. Maka perlu diadakan penjelasan yang mendasar pada anak-anak yang mengalami hambatan dengan memanfaatkan teman yang telah memahami konsep mengenai materi tata cara pelayanan makanan dan minuman di restoran tersebut untuk menjelaskannya. Mendata siswa yang memiliki kemampuan lebih dan mampu untuk menyampaikan materi yang dikuasai kepada temannya.

Perlu dibentuk kelompok-kelompok kecil yang terdiri dari 4-5 orang siswa. Untuk berkolaborasi dalam belajar dan dipimpin oleh siswa yang memiliki kemampuan lebih sebagai tutor dalam menyampaikan materi yang dikuasainya dan juga perlu dibuat suatu catatan-catatan dasar pada siswa yang sering salah dalam mengartikan seperti materi tata cara pelayanan makanan dan minuman di restoran untuk ditindak lanjuti pada tindakan berikutnya.

Pelaksanaan siklus II ini tampak sekali bahwa siswa sangat antusias dalam mengerjakan tugas kelompok, semua siswa terlihat aktif bersama kelompoknya dalam menyelesaikan tugas yang diberikan oleh peneliti. Berdasarkan hasil evaluasi yang telah dilaksanakan dan dikoreksi didaptkan hasil yang sesuai dengan indikator pencapaian hasil yang diharapkan, karena dari 41 siswa kelas XI A5 seluruhnya siswa mampu mendapatkan nilai sesuai KKM atau tuntas dan bahkan banyak siswa yang mencapai nilai di atas KKM, sehingga prosentasi siswa yang telah tuntas adalah $100 \%$. Dari hasil evaluasi yang telah diberikan ternyata seluruhnya siswa mampu mendapatkan nilai sesuai KKM atau tuntas dan bahkan banyak siswa yang mencapai nilai di atas KKM. Aktivitas belajar siswa secara keseluruhan telah sesuai dengan yang diharapkan oleh peneliti karena dalam mengerjakan soal latihan kelompok,siswa aktif berdiskusi bersama tutornya masing-masing.

Penelitian tindakan kelas ini telah dilakukan sesuai dengan tahapan pelaksanaannya, yaitu rencana tindakan, pelaksanaan tindakan, observasi, dan refleksi. Peningkatan aktivitas belajar siswa dari total keseluruhan siswa sebanyak 41 orang pada siklus I dan siklus II di peroleh hasil sebagai berikut: 1) Peserta didik yang aktif mengajukan pertanyaan kepada tutornya dari 39\% meningkat menjadi $76 \%, 2$ ) Peserta didik yang aktif menanggapi pertanyaan dari $15 \%$ meningkat menjadi 49\%, 3) Peserta didik yang aktif menyampaikan pendapat di depan teman sebaya dari $12 \%$ meningkat menjadi $44 \%$, 4) Peserta didik yang aktif berdiskusi bersama teman satu kelompoknya dari $76 \%$ meningkat menjadi $100 \%$, 5) Peserta didik yang aktif memperhatikan materi yang disampaikan oleh tutor dari 54\% meningkat menjadi 76\%,6) Peserta didik yang aktif menulis hal-hal yang penting pada materi yang telah disampaikan oleh tutor dari 44\% meningkat menjadi 76\%, dan 7) Peserta didik yang aktif melakukan tugas-tugas sesuai dengan yang diminta oleh tutor atau gurunya sebanyak $100 \%$ baik di siklus I maupun di siklus II.

Hasil pemahaman belajar siswa menunjukkan bahwa pemahaman belajar siswa terhadap pembelajaran reservasi mengenai penulisan nama tamu meningkat menjadi sangat baik. Hal ini dapat dilihat dari hasil post test yang telah dilaksanakan di siklus I dan siklus II, siswa yang sudah tuntas dalam belajar dari 23 orang menjadi 41 orang, siswa yang sudah tuntas dalam belajar meningkat menjadi $100 \%$ yaitu sebanyak 41 orang. Dengan uraian sebagai berikut: peserta didik yang memperoleh predikat A dengan perolehan skor rerata $3.85-4.00$ yang asalnya berjumlah 2 orang meningkat menjadi 5 orang, peserta didik yang memperoleh Predikat A- dengan perolehan skor rerata 3.51 - 3.84 yang asalnya 
berjumlah 9 orang meningkat menjadi 10 orang, peserta didik yang memperoleh predikat $\mathrm{B}+$ dengan perolehan skor rerata 3.18- 3.50 yang asalnya berjumlah 7 orang meningkat menjadi 11 orang, peserta didik yang memperoleh predikat B dengan prolehan skor rerata 2.85 - 3.17 yang asalnya 5 orang meningkat menjadi 15 orang dan tidak ada siswa yang belum tuntas dalam belajar degan nilai rata - rata pada siklus I (72,56\%) meningkat menjadi $86.22 \%$ ). Jadi dengan menggunakan model Tutor Sebaya (peer tutoring) nilai rata - rata siswa kelas XI A5 SMK Negeri 2 Singaraja Tahun Pelajaran 2017/2018 meningkat $13.66 \%$. Dari hasil angket respon siswa terhadap implementasi model pembelajaran tutor sebaya dapat diketahui bahwa siswa di kelas XI A5 memiliki respon yang tinggi sebesar 64 .

\section{Simpulan Dan Saran}

Berdasarkan hasil penelitian yang telah dilaksanakan, maka dapat disimpulkan bahwa: 1) Aktivitas Belajar Tata Hidang meningkat melalui Implementasi Model Pembelajaran Tutor Sebaya pada Siswa Kelas XI A5 SMK Negeri 2 Singaraja Tahun Pelajaran 2017/2018, hal tersebut dapat terlihat dari aktivitas belajar siswa dalam mata pelajaran tata hidang menunjukkan kriteria sangat aktif yaitu mengajukan pertanyaan kepada tutor sebanyak $76 \%$, berdiskusi bersama teman satu kelompok sebanyak $100 \%$, memperhatikan materi yang disampaikan oleh tutor sebanyak $81 \%$, menulis hal-hal yang penting pada materi yang telah disampaikan oleh tutor sebanyak $76 \%$, melakukan tugas-tugas sesuai dengan yang diminta oleh tutor atau gurunya sebanyak $100 \%$. 2) Hasil Belajar Tata Hidang meningkat melalui Implementasi Model Pembelajaran Tutor Sebaya pada Siswa Kelas XI A5 SMK Negeri 2 Singaraja Tahun Pelajaran 2017/2018, hal tersebut dapat dilihat dari hasil analisis hasil belajar tata hidang menunjukkan bahwa siklus I dan siklus II siswa yang sudah tuntas 23 orang meningkat menjadi 41 orang yang tuntas, siswa yang sudah tuntas dalam belajar meningkat menjadi $100 \%$ yaitu sebanyak 41 orang. Nilai rata- rata yang diperoleh pada siklus I ( $72,56 \%$ ), siklus II meningkat menjadi $86.22 \%$. Jadi dengan menggunakan model Tutor Sebaya (peer tutoring) nilai rata-rata hasil belajar siswa meningkat sebesar 13.66\%. 3) Dari hasil angket respon siswa terhadap implementasi model pembelajaran tutor sebaya dapat diketahui bahwa siswa di kelas XI A5 memiliki respon yang tinggi sebesar 64.

Berdasarkan penelitian yang telah dilaksanakan, dapat disarankan bahwa 1) Siswa kelas XI A5 SMK Negeri 2 Singaraja menunjukkan tanggapan yang baik setelah dilaksanakan model Tutor Sebaya. Melihat hal tersebut peneliti menyarankan kepada guru untuk menggunakan model tutor sebaya sebagai salah satu alternatif pembelajaran tata hidang selanjutnya, 2) Jika menggunakan model tutor sebaya maka dibutuhkan perencanaan yang baik dan pengelolaan waktu yang tepat, 3) Sebelum menerapkan model tutor sebaya, terlebih dahulu guru harus mengetahui kemampuan siswa, sehingga tidak salah ketika akan memilih siswa untuk menjadi tutor.

\section{Daftar Rujukan}

Daryanto.(2008). Evaluasi Pendidikan. Jakarta. Rineka Cipta.

Dimyati dan Mudjiono. (2006). Belajar dan Pembelajaran. Jakarta: Rineka Cipta.

Hamalik O. (2005). Proses Belajar Mengajar. Jakarta: PT Bumi Aksara.

Niken Sholi. (2015). Penerapan Model Tutor Sebaya pada Mata Pelajaran Bahasa Inggris Reported Speech terhadap Hasil Belajar Peserta didik MAN Kota Probolinggo. Jurnal Kebijakan dan Pengembangan Pendidikan. Vol 3 no 1.

Nurmala Nurmala, Sukayasa Sukayasa, Baharuddin Paloloang. (2016). Penerapan Model Pembelajaran Tutor Sebaya Untuk Meningkatkan Hasil Belajar Siswa Kelas V SDN 20 Toli-Toli Pada Operasi Hitung Campuran Bilangan Bulat. Jurnal Kreatif Tadulako Online Untad. Vol 4 No 9.

Sanjaya, Wina. (2009). Strategi Pemebelajaran Berorientasi Standar Proses Pendidikan. Jakarta: Kencana.

Sardiman. (2007). Interaksi \& Motivasi Belajar Mengajar. Bandung: Raja Grafindo Persada.

Slameto. (2003). Belajar dan Faktor-Faktor yang Mempengaruhinya. Jakarta: PT. Rineka Cipta. 
Setiawan, Hendri. (2014). Penerapan Model Pembelajaran Kooperatif tipe NHT (Numbered Head Together) untuk meningkatkan Aktifitas dan Hasil Belajar teknik dasar passing bola basket pada siswa kelas VII SMPN 1 Sukasada. Jurnal PJOK Undiksha. Vol 2, No1.

Sudjana, Nana. (2010). Penilaian Hasil Proses Belajar Mengajar. Bandung: Remaja Rosdakarya.

Tim Penyusun. (2008). Kamus Bahasa Indonesia. Jakarta: Depdiknas 